\title{
Insulin resistance and sarcopenia: mechanistic links between common co-morbidities
}

\author{
Mark E Cleasby', Pauline M Jamieson ${ }^{2}$ and Philip J Atherton ${ }^{3}$ \\ 1Department of Comparative Biomedical Sciences, Royal Veterinary College, University of London, London, UK \\ ${ }^{2}$ Centre for Cardiovascular Science, Queen's Medical Research Institute, University of Edinburgh, Edinburgh, UK \\ ${ }^{3}$ Division of Medical Sciences and Graduate Entry Medicine, University of Nottingham, Medical School, \\ Royal Derby Hospital, Derby, UK
}

Correspondence should be addressed to M E Cleasby Email mcleasby@rvc.ac.uk

\begin{abstract}
Insulin resistance (IR) in skeletal muscle is a key defect mediating the link between obesity and type 2 diabetes, a disease that typically affects people in later life. Sarcopenia (age-related loss of muscle mass and quality) is a risk factor for a number of frailty-related conditions that occur in the elderly. In addition, a syndrome of 'sarcopenic obesity' (SO) is now increasingly recognised, which is common in older people and is applied to individuals that simultaneously show obesity, IR and sarcopenia. Such individuals are at an increased risk of adverse health events compared with those who are obese or sarcopenic alone. However, there are no licenced treatments for sarcopenia or SO, the syndrome is poorly defined clinically and the mechanisms that might explain a common aetiology are not yet well characterised. In this review, we detail the nature and extent of the clinical syndrome, highlight some of the key physiological processes that are dysregulated and discuss some candidate molecular pathways that could be implicated in both metabolic and anabolic defects in skeletal muscle, with an eye towards future therapeutic options. In particular, the potential roles of AKT/mammalian target of rapamycin signalling, AMP-activated protein kinase, myostatin, urocortins and vitamin D are discussed.
\end{abstract}

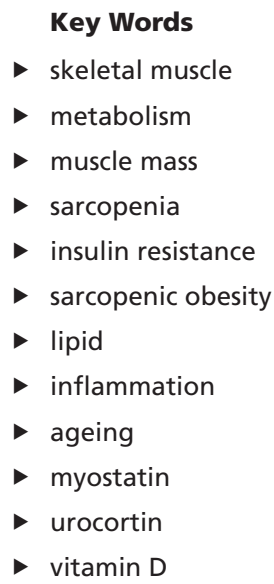

\section{Associations between obesity, diabetes and skeletal muscle ageing}

The International Diabetes Federation has estimated that there were 382 million people living with diabetes in 2013, with this number predicted to rise to 592 million by 2035 , of which the significant majority would be of $>40$ years old (IDF 2013). Of these, $90 \%$ suffer from type 2 diabetes (T2D), which is characterised by both $\beta$-cell failure and resistance to the actions of insulin at the tissue level (insulin resistance, IR). As skeletal muscle is responsible for the majority of the body's postprandial glucose disposal, IR in this tissue results in substantial whole-body metabolic disturbances. However, it is likely that the metabolic disturbances associated with T2D are further exacerbated by the marked loss of skeletal muscle mass that can also be associated with these conditions (Park et al. 2009, Kim et al. 2010). Specifically, loss of muscle mass induces a 2-3\% decline in basal metabolic rate per decade after the age of 20 years and $4 \%$ per decade after the age of 50 years, resulting from concomitant loss of mitochondrial volume density and oxidative capacity (Conley et al. 2000). 
This loss of muscle mass in the elderly is also the principal factor responsible for 'frailty', a syndrome that has been clinically defined as the possession of three of: unintentional weight loss (10 pounds $(\sim 4.5 \mathrm{~kg})$ in the past year), self-reported exhaustion, weakness (poor grip strength), slow walking speed and low physical activity (Fried et al. 2001). Loss of muscle mass (atrophy) is an inevitable, although somewhat modifiable, process that occurs with ageing (Sayer et al. 2008), when it is referred to as primary sarcopenia. In contrast, secondary sarcopenia can result from reduced physical activity or pathological causes, such as cachexia associated with malnutrition, organ failure, inflammatory disease, malignancy or endocrine disease (Cruz-Jentoft et al. 2010). Sarcopenia has been implicated as a risk factor for numerous adverse health outcomes associated with frailty, including weakness, falls and fractures, immobility, functional decline, disability and loss of independence in the elderly (Cruz-Jentoft et al. 2010, Batsis et al. 2014). It has also been associated with increased mortality in some prospective studies (Landi et al. 2013) but not others (Cesari et al. 2009).

The concept of 'sarcopenic obesity' (SO) was introduced to highlight a syndrome present in a group of older patients in whom obesity is accompanied by sarcopenia and IR (Baumgartner 2000). The prevalence of SO in a recent study of adults in the USA was estimated to be $18 \%$ of women and $42 \%$ of men with a mean age of 70 years, with increased risks of mortality being demonstrated for either obese or sarcopenic women (Batsis et al. 2014). However, the significance of concurrent obesity and sarcopenia was really emphasised by a separate study of older people, which demonstrated a 2-3 times higher risk of developing disability associated with reduced activities of daily living in individuals with SO vs others with sarcopenia or obesity alone (Baumgartner et al. 2004). Currently, the characterisation of $\mathrm{SO}$ is as yet confined to a group of clinical and epidemiological observations, rather than being underpinned by defined common mechanisms (Bollheimer et al. 2012). Nevertheless, the apparently high prevalence of SO and its profound consequences for healthcare provision mandates that additional research is carried out into the mechanisms underpinning the syndrome, in order to establish whether the muscle loss and IR associated with SO are indeed inevitable co-morbidities and to identify more effective therapies. The recommended therapeutic interventions are confined to lifestyle changes and are of limited effect, as there are no currently licenced medications for the treatment of sarcopenia (Bouchonville \& Villareal 2013).
In this review, we intend to highlight potential mechanisms and pathways that might underpin both sarcopenia and IR in ageing muscle, which may, in the future, be of interest as therapeutic targets for SO.

\section{Clinical and functional delineation of sarcopenia and SO}

The study of sarcopenia is still hampered by a lack of consensus regarding both definitions and techniques for assessment. Various diagnostic criteria have been used in studies to date; however, these have frequently been established purely on Gaussian distributions of measurements made in the test populations (Baumgartner et al. 1998, Janssen et al. 2002, Newman et al. 2003). More recently, two consensus statements have been issued aiming at defining sarcopenia objectively. The European Working Group on Sarcopenia in Older People stipulated that low muscle mass and either low muscle strength or physical performance should be present for a positive diagnosis to be made (Cruz-Jentoft et al. 2010), whereas the Society of Sarcopenia, Cachexia and Wasting Disorders defined 'sarcopenia with limited mobility' as lean appendicular mass/height ${ }^{2}$ of two SDs or more below the mean for 20-30 year olds, with a walking speed of $\leq 1 \mathrm{~m} / \mathrm{s}$ (Morley et al. 2011).

In addition to the challenges of defining $\mathrm{SO}$, its assessment may be confounded by unchanging or increasing body mass index in older individuals due to increased adiposity, as this will mask any coincident loss of skeletal muscle mass. Therefore, evaluation of SO necessitates the careful assessment of body composition by other methods (Muller et al. 2012). For example, in a recent cross-sectional survey that considered risk factors for and associations with $\mathrm{SO}$ in Korean people $>65$ years, sarcopenia was defined as weight-adjusted dual-X-ray absorptiometrydetermined appendicular skeletal muscle mass $<2$ standard deviations below the mean for healthy young adults (Ryu et al. 2013). In the separate longitudinal Korean Sarcopenic Obesity Study, the extent of visceral obesity at the start of the study was shown to correlate with the extent of loss of appendicular muscle over $\sim 2$ years of follow-up, indicating that there may be a causal component to this association. However, baseline muscle mass was unable to predict the development of obesity (Kim et al. 2014).

A further challenge to the definition and assessment of $\mathrm{SO}$ is that loss of muscle strength with age is substantially more pronounced than loss of mass, suggesting that the

Published by Bioscientifica Ltd. 


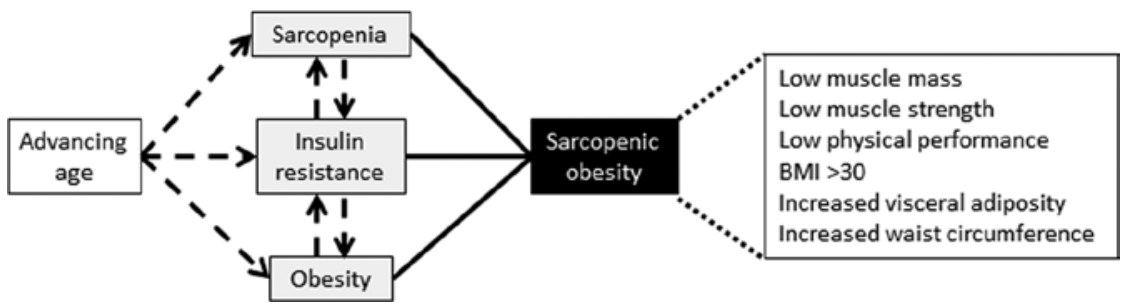

Figure 1

Clinical characterisation of sarcopenic obesity (SO) Sarcopenia, obesity and insulin resistance (IR) increase in prevalence with advancing age. When individuals display several of the clinical signs listed, they may be defined as showing SO. Dotted arrows indicate likely causative relationships and suggest that IR may be central to the syndrome. close relationship between muscle cross-sectional area and mass in younger people is not maintained in sarcopenia (Klein et al. 2002). Moreover, this notion asserts that the loss of skeletal muscle quality is a significant contributor to age-related frailty (Goodpaster et al. 2006). Therefore, the term 'dynapenia' has been proposed as a more clinically relevant alternative to sarcopenia, to reflect the fact that loss of muscle function and mass is not reciprocally related and that the former is more relevant to an increased risk of adverse events, such as falls (reviewed in Manini \& Clark 2012). Indeed, using a tertile-based classification of both muscle strength and adiposity in a small study population, it was shown that the presence of 'dynapenic obesity', but not SO, was predictive of increased risk of falls (Scott et al. 2014). However, as sarcopenia and SO are the terms that are best established in clinical use (Cruz-Jentoft et al. 2010), we have used these terms in this review. A general summary of the factors involved in SO is presented as Fig. 1.

Although numerous animal models have been established to study muscle atrophy associated with disuse (Bodine et al. 2001a), denervation (Muller et al. 2007), sepsis (Breuille et al. 1998), cancer cachexia (Temparis et al. 1994) and glucocorticoid administration (Gardiner et al. 1980), it seems that sarcopenia associated with ageing is mechanistically distinct from acute atrophy induced by such disease processes (Edstrom et al. 2006). Furthermore, the study of bona fide sarcopenia in animal models is hampered by the length of time animals must be housed in order to reach an age at which it is detectable (20-24 months for rodents) (Muller et al. 2007, Bollheimer et al. 2012, Bernet et al. 2014, Tardif et al. 2014, Fry et al. 2015). In addition, studies of animal models of SO demonstrating pathophysiological or molecular mechanisms pertinent to the development of the syndrome in humans have rarely been reported. However, some researchers have studied aged rats with diet-induced obesity (Bollheimer et al. 2012, Tardif et al. 2014), whereas obese Zucker rats are characterised by marked obesity, IR and generalised muscle atrophy (Nilsson et al. 2013), and thus may be useful for the study of SO at a younger age.

\section{IR with respect to skeletal muscle glucose, lipid and protein metabolism}

Peripheral glucose utilisation is reduced as part of the IR that develops with age (Gumbiner et al. 1992) and is substantially impaired in T2D (Cusi et al. 2000); however, protein turnover is also dysregulated. Skeletal muscle accounts for $40-50 \%$ of lean body mass in an adult human and therefore for the majority of whole-body insulinstimulated glucose disposal (Baron et al. 1988, DeFronzo \& Tripathy 2009). Thus, muscle mass is an important determinant of glucose and energy homeostasis (Wolfe 2006) and is determined by the balance between protein synthesis and breakdown in the tissue. An abundant supply of essential amino acids both inhibits proteolysis and stimulates protein synthesis (Castellino et al. 1987, Giordano et al. 1996, Cuthbertson et al. 2005), whereas at least in younger people, insulin has a predominant effect to inhibit protein catabolism in muscle (Fukagawa et al. 1985, Gelfand \& Barrett 1987, Abdulla et al. 2016).

Insulin-mediated accretion of muscle mass has been ascribed to activation of p38 MAPK and mammalian target of rapamycin (mTOR)/p70S6 kinase, and thus stimulation of mRNA translation (Kimball et al. 1998, Guillet et al. 2004a, Fujita et al. 2007). In humans, it is most likely that these effects are mediated through enhanced amino acid availability or delivery through increased perfusion (Fujita et al. 2006, Timmerman et al. 2010), all of which have been reported to be impaired in aged muscle (Bell et al. 2005, Cuthbertson et al. 2005, Rasmussen et al. 2006, Groen et al. 2014). Thus, the concept of age-related 'anabolic resistance' has been proposed to describe the reduced muscle protein synthesis that occurs in response to nutrients (Cuthbertson et al. 2005) or insulin (Rasmussen et al. 2006, Fujita et al. 2009) and the reduced insulinmediated suppression of proteolysis (Guillet et al. 2004b, Wilkes et al. 2009) that is associated with sarcopenia.

Interestingly, resistance to the anabolic action of insulin has been demonstrated in older individuals of normal muscle mass and may therefore precede the physical manifestations of sarcopenia (Rasmussen et al. 2006). Indeed, 
A

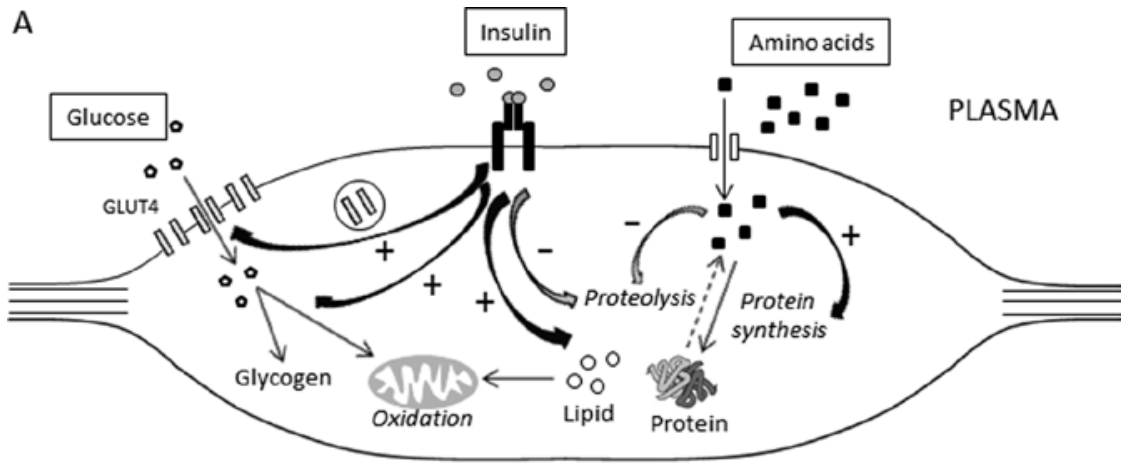

B

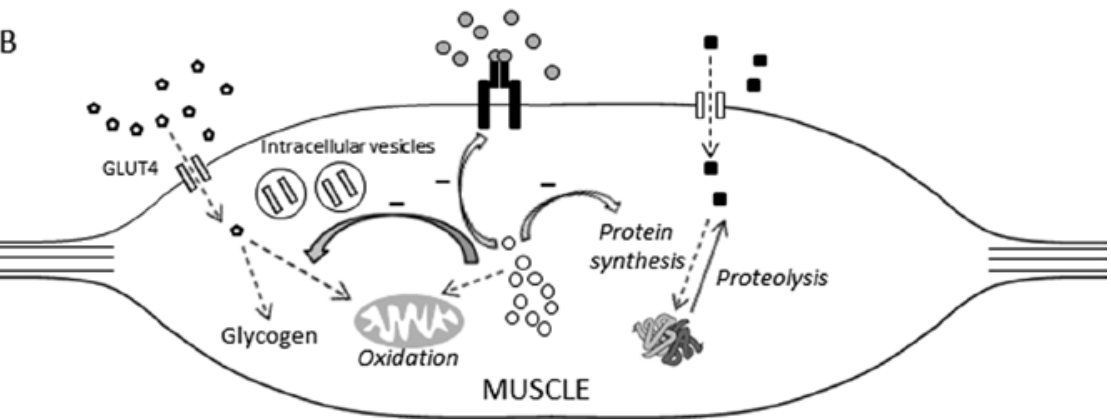

Figure 2

Insulin resistance and 'Anabolic resistance' in skeletal muscle and the role of intramyocellular lipid (IMCL) deposition. (A) Normal muscle of young adult. Protein synthesis predominates over proteolysis under stimulation by supply of essential amino acids and insulin. Optimal insulin sensitivity favours glucose disposal and oxidation of lipids. (B) Muscle of aged adult with sarcopenic obesity. Obesity-associated increases in intramyocellular lipid deposition, among other factors, causes impaired insulin signalling, protein synthesis and glucose metabolism. There is also a reduced anabolic response to exercise, amino acids and insulin. However, the extent of this resistance to insulin on protein, lipid and glucose metabolism varies between individuals. Straight arrows: metabolite flux. Broken straight arrows: reduced metabolite flux. Filled curved arrows: stimulatory effect. Open curved arrows: inhibitory effect.

it seems that differential IR with respect to glucose, protein and lipid metabolism can develop with ageing, IR and SO. For example, many older individuals are sensitive to insulin with regard to glucose metabolism, but not protein synthesis (Fujita et al. 2006). However, insulin, essential amino acids and resistance exercise are all less effective at inducing increases in muscle protein synthesis with increasing adiposity (Guillet et al. 2009, Nilsson et al. 2013, Murton et al. 2015). Metabolite fluxes within young, normal muscle and in muscle from older SO patients are shown in Fig. 2.

Adding further complexity, muscles of differing fibre type composition show contrasting sensitivity of both glucose and protein metabolism to insulin (Lillioja et al. 1987, Baillie and Garlick 1991). T2D is characterised by reduced numbers of predominantly oxidative type I fibres and increased numbers of predominantly glycolytic type II fibres (Oberbach et al. 2006), with the proportion of type I fibres correlating positively with insulin sensitivity (Stuart et al. 2013). Ageing also results in a preferential reduction in the size of type II fibres (Lexell 1995), and the net result is that reduced mitochondrial activity (Johannsen et al. 2012) and IR (Groen et al. 2014, Tardif et al. 2014) may also be evident in muscle. In summary, it appears that IR, loss of muscle mass and changes in muscle fibre type all have the potential to independently or additively alter whole-body glucose homeostasis with ageing.

Clearly, defects that impair insulin-stimulated glucose disposal into muscle and thus negatively impact on wholebody glucose homeostasis will likely be compounded by concurrent sarcopenia, as in SO. It is known that interventions aimed at increasing muscle mass counter the development of IR (Dela et al. 1996); however, it is still not fully appreciated whether this is merely due to a proportionate increase in capacity for glucose disposal, or whether metabolic adaptation works synergistically with an increase in muscle mass. Recent studies in our laboratories have illustrated the potential for a dual effect, as manipulating bioavailability of single proteins in individual muscles, for example by inhibition of myostatin (MSTN; Cleasby et al. 2014), can result in enhanced glucose disposal on a per unit mass basis in

Published by Bioscientifica Ltd 
addition to increased muscle mass and therefore an enhancement in the total capacity for glucose disposal into the tissue.

\section{Possible mechanisms: accumulation of intramyocellular lipid and intermuscular adipocytes}

Both aberrant adipogenesis in muscles and excess intracellular lipid deposition have been associated with impaired muscle mass and insulin sensitivity. Increased adipocyte infiltration between muscle fascicles has been associated with both impaired gait (Scott et al. 2015) and IR (Albu et al. 2005). Furthermore, a longitudinal study demonstrated that progressive loss of muscle mass/quality was associated with increasing intermuscular fat in both ageing humans (Delmonico et al. 2009) and rats (Tardif et al. 2014), whereas another recent paper has shown that cultured intermuscular adipocytes produce pro-diabetic substances, providing evidence of a causal relationship (Laurens et al. 2016). Additionally, a mechanistic link between expansion of visceral adipose tissue and muscle atrophy has been suggested by the observation of reduced expression of contractile proteins in human myotubes co-cultured with visceral adipocytes from obese subjects (Pellegrinelli et al. 2015).

The impact of accumulation of intramyocellular lipid (IMCL) has been thoroughly studied, and there is a wellestablished association between IMCL and muscle IR and T2D. However, triacylglycerol, the main storage form of lipid, is not considered to be mechanistically linked with the development of IR (reviewed in Turner et al. 2014). Instead, the more bioactive derivatives ceramide and diacylglycerol have direct inhibitory effects on insulin signalling and metabolism (Chibalin et al. 2008, Ussher et al. 2010). Increased IMCL has also been associated with impaired muscle function in a number of studies. Lipid infusion results in reduced protein synthesis in response to both amino acids and insulin in healthy human volunteers (Stephens et al. 2015), whereas diet-induced obesity and ectopic deposition of lipid in muscle rather than adipose tissue are also associated with impaired protein synthesis in rodents (Anderson et al. 2008, Masgrau et al. 2012, Tardif et al. 2014). This is associated with increased phosphorylation of elongation factor 2B, a key mediator of ribosomal protein synthesis, in rodent muscle and a saturated fatty acid (SFA)/ceramide-induced increase in elongation factor $2 \alpha$ activation in cultured muscle cells (Tardif et al. 2014). However, the nature of the lipids is important because diets enriched in the SFAs impair muscle protein synthesis in rats than those based on unsaturated fatty acids (Tardif et al. 2011), in addition to their increased tendency to cause IR (Budohoski et al. 1993). The effect of increased IMCL on metabolite fluxes in the muscle of sarcopenic obese patients is shown in Fig. 2.

\section{Inflammation in obesity and in muscle}

Obesity is now recognised to be a subclinical inflammatory state characterised by increased infiltration of adipose tissue with pro-inflammatory cell types, most notably macrophages (Lumeng et al. 2007). Macrophage infiltration has also been demonstrated by a number of groups (Hevener et al. 2007, Fink et al. 2014), but not all (Tam et al. 2012), to be a feature of obesity-associated IR in skeletal muscle, and a synergistic interaction between macrophages and fatty acids that leads to impaired muscle insulin action has been reported (Varma et al. 2009). However, an alternative proposal is that dyslipidaemia associated with obesity activates cellular stress signalling pathways and thereby apoptosis and atrophy in skeletal muscle (Sishi et al. 2011). In particular, SFA can specifically induce pro-inflammatory macrophage activation and consequent p38 MAPK-mediated IR in cultured myotubes, an effect that is ameliorated by the UFA palmitoleate (Talbot et al. 2014). This role of p38 MAPK contrasts with its positive involvement in normal insulin-stimulated glucose disposal into muscle (Kimball et al. 1998), while in addition, loss of skeletal muscle satellite cell self-renewal is associated with impaired $\mathrm{p} 38 \mathrm{MAPK} \alpha / \beta$ activation in aged muscle (Bernet et al. 2014), implying that non-specific inhibition of this kinase is unlikely to yield overall beneficial effects in vivo. The explanation for these apparently disparate roles of p38 MAPK may be distinct functional specificities of the four identified isoforms of the kinase (Brault et al. 2013), a possibility that has not yet been fully investigated.

Further evidence implicates the balance between M1- and M2-type macrophage levels in muscle function. Obesity is characterised by the accumulation of M1-type macrophages, at the relative expense of the M2 subtype (Lumeng et al. 2007). However, muscle expression of M1-related cytokines correlates positively with muscle mass and strength (Beenakker et al. 2013), whereas M2a-type macrophages accumulate in ageing muscle (Wang et al. 2015). Thus, the shift in macrophage phenotype with ageing may be in the opposite direction to that in insulin-resistant muscle.

Published by Bioscientifica Ltd 


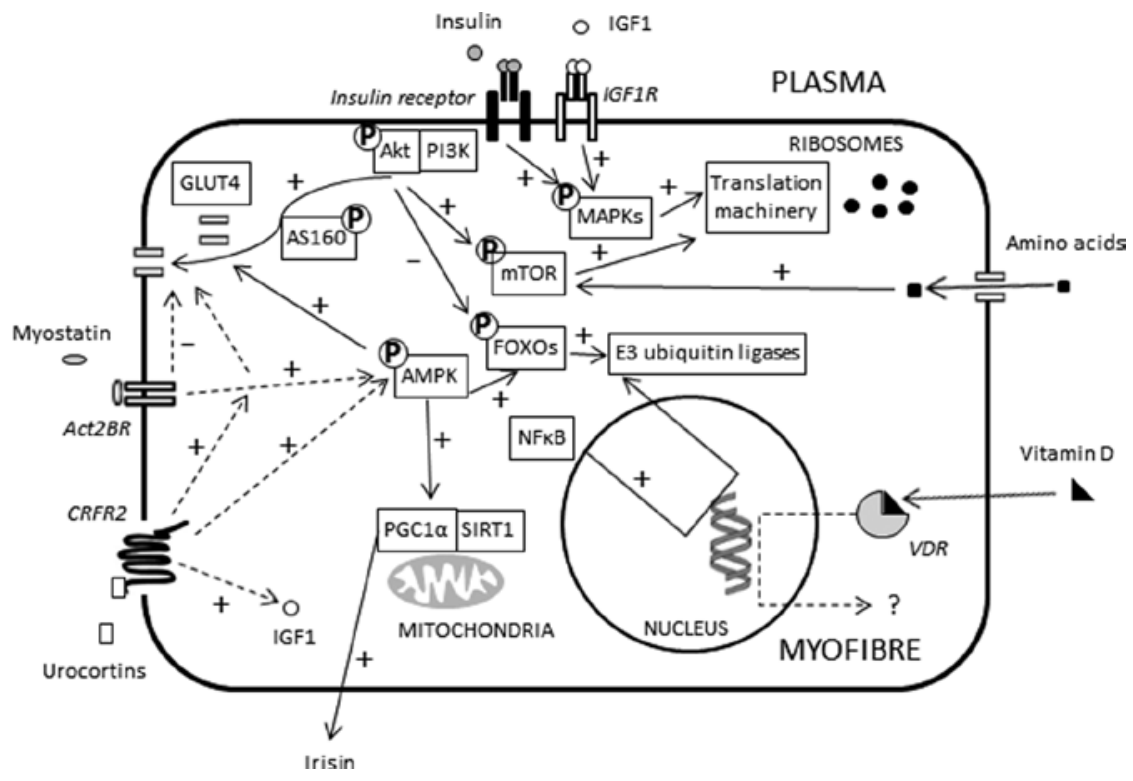

Figure 3

Roles of selected candidate molecular mediators in skeletal muscle glucose and protein metabolism. Published effects of insulin, insulin-like growth factor 1 (IGF1), amino acids, myostatin, urocortins and vitamin D on signalling pathways and effector machinery (glucose transporters, mitochondrial function, translation and activation of E3 ubiquitin ligases) relating to glucose and protein metabolism, as discussed in the text. Unmarked arrow: movement of molecules. Arrow with '+': direct stimulatory effect on expression or activity. Arrow with '-': direct inhibitory effect on expression or activity. Broken arrow: indirect effect. $P$ indicates phosphorylation. ACT2BR, activin 2B receptor; AMPK, AMP-activated protein kinase; AS160, AKT substrate of $160 \mathrm{kDa}$; CRFR2, corticotrophin-releasing factor receptor 2; FOXO, forkhead transcription factor; GLUT4, glucose transporter 4; IGF1R, IGF1 receptor; $\mathrm{NFKB}$, nuclear factor $\mathrm{KB}$; PGC1 $\alpha$, peroxisome proliferator-activated receptor coactivator $1 \alpha$; MAPK, mitogen-activated protein kinase; mTOR, mammalian target of rapamycin; PI3K, phosphoinositol 3-kinase; SIRT1, sirtuin 1; VDR, vitamin D receptor.

Skeletal muscle inflammation is also characterised by activation of the classical signalling pathway to the transcription factor nuclear factor $\kappa \mathrm{B}$ (NF-kB). Chronic activation of this pathway causes profound atrophy in mouse muscle (Cai et al. 2004), while correspondingly it is activated by immobilisation of muscle (Bar-Shai et al. 2005), and targeted ablation of the NF-кB activating enzyme inhibitor $\kappa \mathrm{B}$ kinase 2 (ІКK2) improves skeletal muscle strength, maintains mass and promotes regeneration (Mourkioti et al. 2006). However, short-term muscle fibre-specific overexpression of IкK2 or the p65 subunit of NF-kB, sufficient to cause atrophy, does not impair insulin-stimulated glucose disposal (Polkinghorne et al. 2008), providing further evidence that these two phenotypes are not inextricably linked as part of a pro-inflammatory phenotype.

\section{Other molecular pathways potentially mediating the development of both sarcopenia and IR}

A summary of the roles of the molecules and pathways in glucose and protein metabolism discussed here is shown in Fig. 3.

\section{Phosphatidylinositol 3-kinase/AKT and mTOR signalling}

Insulin and insulin-like growth factor-1 (IGF1) have predominant metabolic and anabolic effects on muscle respectively. However, upon binding to their cognate receptors, both exert their effects by recruitment of intracellular adaptor proteins, including insulin receptor substrate 1 , to the receptor complex and activation of phosphatidylinositol 3-kinase (PI3K). The resulting phosphoinositol triphosphate promotes phosphorylation of protein kinase B/AKT, which then phosphorylates substrates that orchestrate the various physiological effects of the two hormones. Increased glucose disposal is mediated predominantly through phosphorylation of AKT substrate of $160 \mathrm{kDa}$ (TBC1D4) and TBC1D1, and thus movement of GLUT4-containing vesicles to the plasma membrane (Cartee \& Funai 2009), as well as disinhibition of glycogen synthesis by phosphorylation of glycogen synthase kinase 3. AKT mediated activation of mTOR, and thus p70S6 kinase and eukaryotic translation initiation factor $4 \mathrm{E}$-binding protein 1 , is responsible for protein synthesis, and indeed amino acid-stimulated protein synthesis is also mediated through activation of mTOR. In parallel, AKT mediated inhibition of forkhead transcription factor (FOXO) activity reduces

Published by Bioscientifica Ltd. 
expression of the E3 ubiquitin ligases that are principally responsible for mediating atrophy (atrogin-1/muscle atrophy F-box and muscle RING finger 1; Schiaffino et al. 2013).

Consequently, activation of proximal PI3K pathways would be expected to have dual positive effects on muscle size and metabolism. This is clearly illustrated by muscle overexpression of Akt in rodents, which causes both muscle hypertrophy and increased glucose disposal per unit muscle mass, with the predominant effects determined by the isoform used (AKT 1 vs AKT 2-predominant effects, respectively; Bodine et al. 2001b, Cleasby et al. 2007). Furthermore, defects in both components of the pathway were identified in leptin receptor-null $(\mathrm{db} / \mathrm{db})$ mice and obese Zucker rats. Treatment with the insulin-sensitising thiazolidinedione drug rosiglitazone also led to an improvement in muscle mass, leading to the suggestion that IR per se could cause muscle wasting through suppression of PI3K/AKT signalling (Wang et al. 2006, Katta et al. 2010). However, it is equally plausible that activation of the AKT-mTOR cellular signalling pathways following peroxisome proliferator-activated receptor (PPAR) $\gamma$ stimulation by rosiglitazone impacts positively on both IR and muscle mass. The physiological relevance of this is unclear, as impairment of the AKT-mTOR pathway in muscle does not seem to occur naturally in ageing humans or mice (Sandri et al. 2013); however, it may yet represent a therapeutic target.

\section{AMP-activated protein kinase (AMPK)}

AMPK is a cellular energy sensor that is activated by an increased AMP:ATP ratio, leading to increased glucose and fatty acid uptake and oxidation in skeletal muscle (Koh et al. 2008). It plays a major role in coordinating energy use during exercise in muscle, but also mediates the long-term effects of exercise, through mitochondrial biogenesis. This process is initiated by AMPK-mediated activation of silent mating-type information regulator 2 homolog 1 (SIRT1) and PPAR coactivator- $1 \alpha$ (PGC1 $\alpha$ ) (Mounier et al. 2015). AMPK has been extensively studied as a potential molecular target for the development of novel therapies for T2D (Coughlan et al. 2014), and recent work has identified an additional role for AMPK in muscle turnover/plasticity. It can protect against age-related functional and mitochondrial impairment by promoting myocyte macroautophagy, an essential process for cellular maintenance (Bujak et al. 2015). AMPK likely mediates the effects of adiponectin to promote macroautophagy (Liu et al. 2015), which partly mediates this adipokine's insulin-sensitising effect in muscle
(Patel et al. 2012). However, the effects of AMPK on muscle mass appear less favourable. A study of ageing rodents showed an inverse relationship between activating AMPK phosphorylation and load-induced hypertrophy (Thomson \& Gordon 2005). Furthermore, AMPK stimulates myofibrillar protein degradation through increased FOXO expression (Nakashima \& Yakabe 2007) and causes down-regulation of the mTOR pathway, thus restricting protein synthesis (Bolster et al. 2002). In addition, liver kinase b1, one of AMPK's upstream kinases, has been shown to limit differentiation of satellite cells (stem cells present in adult skeletal muscle) through the same mechanism (Shan et al. 2014). Thus, further studies are necessary to ascertain whether AMPK activation would have a net beneficial effect in individuals with both IR and sarcopenia.

\section{Myostatin}

MSTN is now well established as a central determinant of muscle size and mass, as demonstrated by the pronounced increases in muscle mass caused by gene-inactivating mutations in mice (McPherron et al. 1997) and by naturally occurring genetic loss-of-function variants in several domestic species (Hill et al. 2010). Consistent with this, its expression has also been shown to be increased in sarcopenia in some studies (Leger et al. 2008); however, this has not been a universal finding (Ratkevicius et al. 2011).

However, in addition to its effects on muscle mass, MSTN deficiency has more recently been shown to have beneficial effects on metabolism, adiposity and insulin sensitivity. Both Mstn-null mice (Guo et al. 2009) and mice treated with either soluble MSTN receptor activin receptor IIb (Akpan et al. 2009), which sequesters the mature peptide in the plasma, or the natural inhibitor follistatin-like 3 (Brandt et al. 2015) show increased muscle glucose utilisation and insulin sensitivity, associated with increased lean mass and decreased fat mass.

Genetic or pharmacological inactivation of MSTN increases activation of AMPK (Zhang et al. 2011), increases lipolysis and fatty acid oxidation in peripheral tissues, and also increases the expression of brown adipocyte markers in white adipose tissue (Zhang et al. 2012), providing a number of potential mechanisms for its metabolic activity. Importantly, we have also recently shown that short-term local impairment of MSTN action in rats by overexpression of the MSTN propeptide and sequestration of the active peptide enhances skeletal muscle glucose disposal to a greater extent than would be expected due to increased muscle mass alone, implying that additive or synergistic mechanisms are in operation.

Published by Bioscientifica Ltd 
The associated increase in glucose transporter (GLUT1 and GLUT4) protein levels may underpin the metabolic effects observed (Cleasby et al. 2014).

A number of modalities utilising inhibition of MSTN activity as a therapeutic approach have not yet borne fruit, although antisense-mediated destructive exon skipping is currently being evaluated. This has shown some promise in preserving muscle mass in a mouse model of Duchenne muscular dystrophy (Lu-Nguyen et al. 2015), and its metabolic effects are currently under investigation.

\section{Urocortins}

Urocortins (Ucns) are neuropeptide ligands for the corticotrophin-releasing factor receptor 2 (CRFR2) that are expressed not only in the central nervous system but also in peripheral metabolic tissues. There are particularly high levels of UCN2 and CRFR2 in skeletal muscle (Chen et al. 2006), implying that these 'stress regulators' play a role in muscle physiology. Furthermore, Crfr 2 expression was reduced on an average by 71 and $92 \%$ in the soleus and tibialis cranialis muscles, respectively, of aged mice 24 vs 3 month old; $n=6, P<0.001$ ).

Global knockout of either Ucn2 or Crfr2 produced mice that were resistant to diet-induced obesity and IR (Bale et al. 2003, Chen et al. 2006), the former also demonstrating increased muscle mass. Interestingly, however, global overexpression of $U c n 3$ also resulted in mice with marked muscular hypertrophy. These mice had increased Igf1 expression in muscle and also resisted the increased adiposity and metabolic abnormalities associated with feeding a high-fat diet, despite the lack of endogenous muscle Ucn3 expression (Jamieson et al. 2011). In order to dissect the muscle-autonomous component of this phenotype further and to indicate whether CRFR2 might have the potential as a therapeutic target, we performed short-term overexpression of Ucn3 in rat muscle and showed increased glucose disposal, associated with elevated levels of glucose transporter expression, and phosphorylation of both AMPK and insulin signalling intermediates, before any increased muscle mass was detectable (Roustit et al. 2014). Thus, a strategy to target CRFR2 may also have the potential to improve muscle mass and metabolism additively.

\section{Vitamin D}

There has recently been renewed interest in potential novel roles for vitamin $\mathrm{D}$, including in the maintenance of muscle mass and insulin sensitivity, which has been provoked in part by the identification of a high prevalence of vitamin D deficiency among adults (Bates et al. 2011). Profound dietary insufficiency leads to impaired muscle strength as a result of hypophosphataemia in rats (Schubert \& DeLuca 2010). However, epidemiological and intervention studies in humans have yielded contradictory results with regard to the role of vitamin D in muscle mass/function and metabolic endpoints. For example, insulin sensitivity has been reported to be either improved or unaffected by vitamin D supplementation (Talaei et al. 2013, Wongwiwatthananukit et al. 2013). Vitamin D supplementation was reported to increase muscle fibre size in immobile older women (Ceglia et al. 2013); however, a recent systematic review of studies showed a benefit of supplementation for individuals with vitamin D deficiency at the start of the trial in terms of improved muscle strength, but not in muscle mass or power (maximum force generated in minimum time; Beaudart et al. 2014). These contradictory findings might be a result of insufficient study power and/or imprecise subject selection in many instances.

Attempts to explain a hypothesised role for vitamin $\mathrm{D}$ in muscle on a molecular level have been few to date; however, knockout of the vitamin D receptor $(V d r)$ in mice resulted in reduced muscle size, impaired motor activity (Burne et al. 2006) and abnormal muscle development (Endo et al. 2003), In addition, Vdr-null mice are leaner (Narvaez et al. 2009), possibly due to increased uncoupling protein expression (Wong et al. 2009), but conversely have recently been shown to be insulin resistant, a phenotype that was shown to be mediated through increased muscle FOXO1 activation (Chen et al. 2016). Further work is needed to define the mechanistic links between vitamin D, the VDR and ageing-related phenotypes.

\section{Additional therapeutic perspectives}

Sarcopenia (Baumgartner et al. 1999, Raguso et al. 2006, Lee et al. 2007, Park et al. 2010, Genton et al. 2011, Scott et al. 2011, Szulc et al. 2004) and SO (Ryu et al. 2013) have been associated with low levels of physical activity in both cross-sectional and longitudinal studies, whereas exercisebased interventions are well established to improve both muscle mass and performance (Skelton et al. 1995, Vincent et al. 2002) and insulin sensitivity (Fujita et al. 2007) in aged individuals. However, it is clear that these interventions are of more use in the prevention, rather than treatment, of sarcopenia or SO and metabolic

Published by Bioscientifica Ltd 
dysfunction, as elderly individuals are often too frail to undertake the degree of exercise required to achieve a beneficial effect (Wolfe 2006), while they may also suffer from anabolic resistance.

In addition, it is clear that a profound reduction in dietary energy intake can have a remarkable effect to alleviate IR and T2D (Steven \& Taylor 2015). However, the inevitable lean tissue mass that is lost using this approach alone renders it undesirable in the already sarcopenic elderly, unless concurrent exercise or appropriate nutritional supplementation is undertaken (Yoshimura et al. 2014, Verreijen et al. 2015). Although a comprehensive assessment of dietary approaches is out with the scope of this review, it is clear that motivation and compliance can frequently be a major limiting factor in the success of such lifestyle interventions (Evangelista et al. 2003).

In terms of current pharmacotherapy, androgen replacement in hypogonadal men is effective in increasing muscle mass; however, its use is as yet unproven in normal ageing individuals and is accompanied by undesirable side effects (Giannoulis et al. 2012). Nevertheless, androgen use may also be associated with an improvement in insulin sensitivity (Traish et al. 2009). The development of selective androgen receptor-modulating therapies may help mitigate many of these side effects. Preclinical and phase II trials of candidate drugs have demonstrated beneficial effects on insulin sensitivity as well as on muscle mass and strength (Gao et al. 2005, Dalton et al. 2011, Min et al. 2009).

One possible novel therapeutic approach might be to stimulate satellite cell activity and thus myofibre regeneration or replacement (Bernet et al. 2014), with the intention not only of improving muscle strength but also the capacity for glucose disposal. However, satellite cell ablation in adult mice did not affect age-related sarcopenia in a recent study (Fry et al. 2015), implying that strategies aimed at stimulating their fusion or proliferation may not be effective. Furthermore, chronic activation of pathways triggering muscle growth, such as the IGF1AKT pathway (Bellacosa et al. 2005), involves the activation of known oncogenes, and thus the risk of tumour development.

PGC1 $\alpha$ is another molecular target that might be a promising candidate for alleviation of both metabolic inefficiency and sarcopenia. This molecule is regarded as a key mediator of the beneficial effects of endurance exercise. Increased expression of $\mathrm{PGC} 1 \alpha$ in muscle improves metabolic fitness and prevents sarcopenia in ageing mice (Wenz et al. 2009), although it is unclear whether it promotes muscle strength in addition. Activation of PGC1 $\alpha$ has been shown to result in increased secretion of a novel hormone, irisin, which alleviates IR in mice (Bostrom et al. 2012), although the significance of this finding for human biology has been questioned (Timmons et al. 2012, Raschke et al. 2013). Nevertheless, there is much interest in designing an 'exercise mimetic' drug, based on such a molecular target, which would improve both muscle mass/function and metabolism, to tackle obesity-related metabolic disorders. However, it would seem unlikely that an approach aimed at targeting a single mediator would be successful in human trials.

\section{Conclusions and challenges for the future}

This review has discussed current knowledge of the physiological and molecular mechanisms that govern both atrophy/sarcopenia and IR in skeletal muscle. We have aimed to highlight potential common ground between these mechanisms that could point to future development of novel therapies for SO in the elderly.

A number of challenges remain to address the deficiencies in our knowledge of this syndrome:

(i) To establish a robust clinical definition of $\mathrm{SO}$ to enhance study design and thus permit improved comparability between clinical studies.

(ii) To establish whether sarcopenia and muscle IR are in fact inevitable co-morbidities, given the substantial overlap in the molecular pathways that are dysregulated in each.

(iii) To develop a more suitable animal model for SO to permit more practical mechanistic studies and preclinical therapeutic trials.

(iv) To further elucidate the key molecular pathways mediating both pathologies, permitting identification of molecular targets suitable for the development of combined therapies.

Addressing these priorities will hopefully provide a sounder footing to attempt more rational treatment of this common and debilitating condition.

\section{Declaration of interest}

The authors declare that there is no conflict of interest that could be perceived as prejudicing the impartiality of this review.

\section{Funding}

This work was funded by a Wellcome Trust University Award (087461) and a Diabetes UK project grant (BDA 13/0004683).

Published by Bioscientifica Ltd. 


\section{Author contribution statement}

M E C wrote the principal drafts, and P M J and P J A revised the initial draft and approved the final version of the manuscript.

\section{Acknowledgements}

The authors apologise to colleagues whose publications have not been included due to space constraints.

\section{References}

Abdulla H, Smith K, Atherton PJ \& Idris I 2016 Role of insulin in the regulation of human skeletal muscle protein synthesis and breakdown: a systematic review and meta-analysis. Diabetologia 59 44-55. (doi:10.1007/s00125-015-3751-0)

Akpan I, Goncalves MD, Dhir R, Yin X, Pistilli EE, Bogdanovich S, Khurana TS, Ucran J, Lachey J \& Ahima RS 2009 The effects of a soluble activin type IIB receptor on obesity and insulin sensitivity. International Journal of Obesity 33 1265-1273. (doi:10.1038/ ijo.2009.162)

Albu JB, Kovera AJ, Allen L, Wainwright M, Berk E, Raja-Khan N, Janumala I, Burkey B, Heshka S \& Gallagher D 2005 Independent association of insulin resistance with larger amounts of intermuscular adipose tissue and a greater acute insulin response to glucose in African American than in white nondiabetic women. American Journal of Clinical Nutrition 82 1210-1217.

Anderson SR, Gilge DA, Steiber AL \& Previs SF 2008 Diet-induced obesity alters protein synthesis: tissue-specific effects in fasted versus fed mice. Metabolism 57 347-354. (doi:10.1016/j.metabol.2007.10.009)

Baillie AG \& Garlick PJ 1991 Responses of protein synthesis in different skeletal muscles to fasting and insulin in rats. American Journal of Physiology 260 E891-E896.

Bale TL, Anderson KR, Roberts AJ, Lee KF, Nagy TR \& Vale WW 2003 Corticotropin-releasing factor receptor-2-deficient mice display abnormal homeostatic responses to challenges of increased dietary fat and cold. Endocrinology 144 2580-2587. (doi:10.1210/en.2002-0091)

Baron AD, Brechtel G, Wallace P \& Edelman SV 1988 Rates and tissue sites of non-insulin- and insulin-mediated glucose uptake in humans. American Journal of Physiology 255 E769-E774.

Bar-Shai M, Carmeli E \& Reznick AZ 2005 The role of NF-kappaB in protein breakdown in immobilization, aging, and exercise: from basic processes to promotion of health. Annals of the New York Academy of Sciences 1057 431-447. (doi:10.1196/annals.1356.034)

Bates B, Bates C, Prentice P \& Swan G 2011 National Diet and Nutrition Survey Headline results from Years 1 and 2 (combined) of the Rolling Programme (2008/2009-2009/10). Supplementary Report: Blood analytes. London, UK: Department of Health and the Food Standards Agency. (available at: https://www.gov.uk/government/uploads/ system/uploads/attachment_data/file/215348/dh_130788.pdf)

Batsis JA, Mackenzie TA, Barre LK, Lopez-Jimenez F \& Bartels SJ 2014 Sarcopenia, sarcopenic obesity and mortality in older adults: results from the National Health and Nutrition Examination Survey III. European Journal of Clinical Nutrition 68 1001-1007. (doi:10.1038/ ejcn.2014.117)

Baumgartner RN 2000 Body composition in healthy aging. Annals of the New York Academy of Sciences 904 437-448. (doi:10.1111/j.1749-6632.2000.tb06498.x)

Baumgartner RN, Koehler KM, Gallagher D, Romero L, Heymsfield SB, Ross RR, Garry PJ \& Lindeman RD 1998 Epidemiology of sarcopenia among the elderly in New Mexico. American Journal of Epidemiology 147 755-763. (doi:10.1093/oxfordjournals.aje.a009520)

Baumgartner RN, Waters DL, Gallagher D, Morley JE \& Garry PJ 1999 Predictors of skeletal muscle mass in elderly men and women.
Mechanisms of Ageing and Development 107 123-136. (doi:10.1016/ S0047-6374(98)00130-4)

Baumgartner RN, Wayne SJ, Waters DL, Janssen I, Gallagher D \& Morley JE 2004 Sarcopenic obesity predicts instrumental activities of daily living disability in the elderly. Obesity Research 12 1995-2004. (doi:10.1038/oby.2004.250)

Beaudart C, Buckinx F, Rabenda V, Gillain S, Cavalier E, Slomian J, Petermans J, Reginster JY \& Bruyere O 2014 The effects of vitamin D on skeletal muscle strength, muscle mass, and muscle power: a systematic review and meta-analysis of randomized controlled trials. Journal of Clinical Endocrinology and Metabolism 99 4336-4345. (doi:10.1210/jc.2014-1742)

Beenakker KG, Westendorp RG, de Craen AJ, Slagboom PE, van Heemst D \& Maier AB 2013 Pro-inflammatory capacity of classically activated monocytes relates positively to muscle mass and strength. Aging Cell 12 682-689. (doi:10.1111/acel.12095)

Bell JA, Fujita S, Volpi E, Cadenas JG \& Rasmussen BB 2005 Short-term insulin and nutritional energy provision do not stimulate muscle protein synthesis if blood amino acid availability decreases. American Journal of Physiology: Endocrinology and Metabolism 289 E999-E1006.

Bellacosa A, Kumar CC, Di Cristofano A \& Testa JR 2005 Activation of AKT kinases in cancer: implications for therapeutic targeting. Advances in Cancer Research 94 29-86. (doi:10.1016/S0065230X(05)94002-5)

Bernet JD, Doles JD, Hall JK, Kelly Tanaka K, Carter TA \& Olwin BB 2014 p38 MAPK signaling underlies a cell-autonomous loss of stem cell self-renewal in skeletal muscle of aged mice. Nature Medicine 20 265-271. (doi:10.1038/nm.3465)

Bodine SC, Latres E, Baumhueter S, Lai VK, Nunez L, Clarke BA, Poueymirou WT, Panaro FJ, Na E, Dharmarajan K, et al. 2001 a Identification of ubiquitin ligases required for skeletal muscle atrophy. Science 294 1704-1708.

Bodine SC, Stitt TN, Gonzalez M, Kline WO, Stover GL, Bauerlein R, Zlotchenko E, Scrimgeour A, Lawrence JC, Glass DJ, et al. 2001b Akt/ mTOR pathway is a crucial regulator of skeletal muscle hypertrophy and can prevent muscle atrophy in vivo. Nature Cell Biology 3 1014-1019.

Bollheimer LC, Buettner R, Pongratz G, Brunner-Ploss R, Hechtl C, Banas M, Singler K, Hamer OW, Stroszczynski C, Sieber CC, et al. 2012 Sarcopenia in the aging high-fat fed rat: a pilot study for modeling sarcopenic obesity in rodents. Biogerontology 13 609-620. (doi:10.1007/s10522-012-9405-4)

Bolster DR, Crozier SJ, Kimball SR \& Jefferson LS 2002 AMP-activated protein kinase suppresses protein synthesis in rat skeletal muscle through down-regulated mammalian target of rapamycin (mTOR) signaling. Journal of Biological Chemistry 277 23977-23980. (doi:10.1074/jbc.C200171200)

Bostrom P, Wu J, Jedrychowski MP, Korde A, Ye L, Lo JC, Rasbach KA, Bostrom EA, Choi JH, Long JZ, et al. 2012 A PGC1-alpha-dependent myokine that drives brown-fat-like development of white fat and thermogenesis. Nature 481 463-468. (doi:10.1038/nature10777)

Bouchonville MF \& Villareal DT 2013 Sarcopenic obesity: how do we treat it? Current Opinion in Endocrinology, Diabetes, and Obesity 20 412-419. (doi:10.1097/01.med.0000433071.11466.7f)

Brandt C, Hansen RH, Hansen JB, Olsen CH, Galle P, Mandrup-Poulsen T, Gehl J, Pedersen BK \& Hojman P 2015 Over-expression of Follistatinlike 3 attenuates fat accumulation and improves insulin sensitivity in mice. Metabolism 64 283-295. (doi:10.1016/j.metabol.2014.10.007)

Brault JJ, Pizzimenti NM, Dentel JN \& Wiseman RW 2013 Selective inhibition of ATPase activity during contraction alters the activation of p38 MAP kinase isoforms in skeletal muscle. Journal of Cellular Biochemistry 114 1445-1455. (doi:10.1002/jcb.24486)

Breuille D, Arnal M, Rambourdin F, Bayle G, Levieux D \& Obled C 1998 Sustained modifications of protein metabolism in various tissues in a rat model of long-lasting sepsis. Clinical Science 94 413-423. (doi:10.1042/cs0940413) 
Budohoski L, Panczenko-Kresowska B, Langfort J, Zernicka E, Dubaniewicz A, Ziemlanski S, Challiss RA \& Newsholme EA 1993 Effects of saturated and polyunsaturated fat enriched diet on the skeletal muscle insulin sensitivity in young rats. Journal of Physiology and Pharmacology 44 391-398.

Bujak AL, Crane JD, Lally JS, Ford RJ, Kang SJ, Rebalka IA, Green AE, Kemp BE, Hawke TJ, Schertzer JD, et al. 2015 AMPK Activation of Muscle Autophagy Prevents Fasting-Induced Hypoglycemia and Myopathy during Aging. Cell Metabolism 21 883-890. (doi:10.1016/j. cmet.2015.05.016)

Burne TH, Johnston AN, McGrath JJ \& Mackay-Sim A 2006 Swimming behaviour and post-swimming activity in Vitamin D receptor knockout mice. Brain Research Bulletin 69 74-78. (doi:10.1016/j. brainresbull.2005.10.014)

Cai D, Frantz JD, Tawa NE Jr, Melendez PA, Oh BC, Lidov HG, Hasselgren PO, Frontera WR, Lee J, Glass DJ, et al. 2004 IKKbeta/ NF-kappaB activation causes severe muscle wasting in mice. Cell 119 285-298. (doi:10.1016/j.cell.2004.09.027)

Cartee GD \& Funai K 2009 Exercise and insulin: Convergence or divergence at AS160 and TBC1D1? Exercise and Sport Sciences Reviews 37 188-195.

Castellino P, Luzi L, Simonson DC, Haymond M \& DeFronzo RA 1987 Effect of insulin and plasma amino acid concentrations on leucine metabolism in man. Role of substrate availability on estimates of whole body protein synthesis. Journal of Clinical Investigation $\mathbf{8 0}$ 1784-1793. (doi:10.1172/JCI113272)

Ceglia L, Niramitmahapanya S, da Silva Morais M, Rivas DA, Harris SS, Bischoff-Ferrari H, Fielding RA \& Dawson-Hughes B 2013 A randomized study on the effect of vitamin $\mathrm{D}(3)$ supplementation on skeletal muscle morphology and vitamin D receptor concentration in older women. Journal of Clinical Endocrinology and Metabolism $\mathbf{9 8}$ E1927-E1935.

Cesari M, Pahor M, Lauretani F, Zamboni V, Bandinelli S, Bernabei R, Guralnik JM \& Ferrucci L 2009 Skeletal muscle and mortality results from the InCHIANTI Study. Journals of Gerontology. Series A, Biological Sciences and Medical Sciences 64 377-384.

Chen A, Brar B, Choi CS, Rousso D, Vaughan J, Kuperman Y, Kim SN, Donaldson C, Smith SM, Jamieson P, et al. 2006 Urocortin 2 modulates glucose utilization and insulin sensitivity in skeletal muscle. PNAS 103 16580-16585. (doi:10.1073/pnas.0607337103)

Chen S, Villalta SA \& Agrawal DK 2016 FOXO1 Mediates vitamin D deficiency-induced insulin resistance in skeletal muscle. Journal of Bone and Mineral Research 31 585-595. (doi:10.1002/jbmr.2729)

Chibalin AV, Leng Y, Vieira E, Krook A, Bjornholm M, Long YC, Kotova O, Zhong Z, Sakane F, Steiler T, et al. 2008 Downregulation of diacylglycerol kinase delta contributes to hyperglycemia-induced insulin resistance. Cell 132 375-386. (doi:10.1016/j.cell.2007.12.035)

Cleasby ME, Reinten TA, Cooney GJ, James DE \& Kraegen EW 2007 Functional studies of Akt isoform specificity in skeletal muscle in vivo; maintained insulin sensitivity despite reduced insulin receptor substrate-1 expression. Molecular Endocrinology 21 215-228. (doi:10.1210/me.2006-0154)

Cleasby ME, Jarmin S, Eilers W, Elashry M, Andersen DK, Dickson G \& Foster K 2014 Local overexpression of the myostatin propeptide increases glucose transporter expression and enhances skeletal muscle glucose disposal. American Journal of Physiology. Endocrinology and Metabolism 306 E814-E823.

Conley KE, Jubrias SA \& Esselman PC 2000 Oxidative capacity and ageing in human muscle. Journal of Physiology 526 203-210. (doi:10.1111/j.1469-7793.2000.t01-1-00203.x)

Coughlan KA, Valentine RJ, Ruderman NB \& Saha AK 2014 AMPK activation: a therapeutic target for type 2 diabetes? Diabetes, Metabolic Syndrome and Obesity 7 241-253.

Cruz-Jentoft AJ, Baeyens JP, Bauer JM, Boirie Y, Cederholm T, Landi F, Martin FC, Michel JP, Rolland Y, Schneider SM, et al. 2010 Sarcopenia: European consensus on definition and diagnosis: Report of the
European Working Group on Sarcopenia in Older People. Age and Ageing 39 412-423.

Cusi K, Maezono K, Osman A, Pendergrass M, Patti ME, Pratipanawatr T, DeFronzo RA, Kahn CR \& Mandarino LJ 2000 Insulin resistance differentially affects the PI 3-kinase- and MAP kinase-mediated signaling in human muscle. Journal of Clinical Investigation $\mathbf{1 0 5}$ 311-320. (doi:10.1172/JCI7535)

Cuthbertson D, Smith K, Babraj J, Leese G, Waddell T, Atherton P, Wackerhage H, Taylor PM \& Rennie MJ 2005 Anabolic signaling deficits underlie amino acid resistance of wasting, aging muscle. FASEB Journal 19 422-424.

Dalton JT, Barnette KG, Bohl CE, Hancock ML, Rodriguez D, Dodson ST, Morton RA \& Steiner MS 2011 The selective androgen receptor modulator GTx-024 (enobosarm) improves lean body mass and physical function in healthy elderly men and postmenopausal women: results of a double-blind, placebo-controlled phase II trial. Journal of Cachexia, Sarcopenia and Muscle 2 153-161. (doi:10.1007/13539.2190-6009)

DeFronzo RA \& Tripathy D 2009 Skeletal muscle insulin resistance is the primary defect in type 2 diabetes. Diabetes Care $\mathbf{3 2}$ (Supplement 2) S157-S163.

Dela F, Mikines KJ, Larsen JJ \& Galbo H 1996 Training-induced enhancement of insulin action in human skeletal muscle: the influence of aging. Journals of Gerontology. Series A, Biological Sciences and Medical Sciences 51 B247-B252.

Delmonico MJ, Harris TB, Visser M, Park SW, Conroy MB, VelasquezMieyer P, Boudreau R, Manini TM, Nevitt M, Newman AB, et al. 2009 Longitudinal study of muscle strength, quality, and adipose tissue infiltration. American Journal of Clinical Nutrition 90 1579-1585. (doi:10.3945/ajcn.2009.28047)

Edstrom E, Altun M, Hagglund M \& Ulfhake B 2006 Atrogin-1/MAFbx and MuRF1 are downregulated in aging-related loss of skeletal muscle. Journals of Gerontology. Series A, Biological Sciences and Medical Sciences 61 663-674. (doi:10.1093/gerona/61.7.663)

Endo I, Inoue D, Mitsui T, Umaki Y, Akaike M, Yoshizawa T, Kato S \& Matsumoto T 2003 Deletion of vitamin D receptor gene in mice results in abnormal skeletal muscle development with deregulated expression of myoregulatory transcription factors. Endocrinology 144 5138-5144. (doi:10.1210/en.2003-0502)

Evangelista L, Doering LV, Dracup K, Westlake C, Hamilton M \& Fonarow GC 2003 Compliance behaviors of elderly patients with advanced heart failure. Journal of Cardiovascular Nursing 18 197-206; quiz 207-198.

Fink LN, Costford SR, Lee YS, Jensen TE, Bilan PJ, Oberbach A, Bluher M, Olefsky JM, Sams A \& Klip A 2014 Pro-Inflammatory macrophages increase in skeletal muscle of high fat-Fed mice and correlate with metabolic risk markers in humans. Obesity 22 747-757. (doi:10.1002/ oby.20615)

Fried LP, Tangen CM, Walston J, Newman AB, Hirsch C, Gottdiener J, Seeman T, Tracy R, Kop WJ, Burke G, et al. 2001 Frailty in older adults: evidence for a phenotype. Journals of Gerontology. Series A, Biological Sciences and Medical Sciences 56 M146-M156.

Fry CS, Lee JD, Mula J, Kirby TJ, Jackson JR, Liu F, Yang L, Mendias CL, Dupont-Versteegden EE, McCarthy JJ, et al. 2015 Inducible depletion of satellite cells in adult, sedentary mice impairs muscle regenerative capacity without affecting sarcopenia. Nature Medicine 21 76-80.

Fujita S, Rasmussen BB, Cadenas JG, Grady JJ \& Volpi E 2006 Effect of insulin on human skeletal muscle protein synthesis is modulated by insulin-induced changes in muscle blood flow and amino acid availability. American Journal of Physiology: Endocrinology and Metabolism 291 E745-E754.

Fujita S, Rasmussen BB, Cadenas JG, Drummond MJ, Glynn EL, Sattler FR \& Volpi E 2007 Aerobic exercise overcomes the age-related insulin resistance of muscle protein metabolism by improving endothelial function and Akt/mammalian target of rapamycin signaling. Diabetes 56 1615-1622. (doi:10.2337/db06-1566) 
Fujita S, Glynn EL, Timmerman KL, Rasmussen BB \& Volpi E 2009 Supraphysiological hyperinsulinaemia is necessary to stimulate skeletal muscle protein anabolism in older adults: evidence of a true age-related insulin resistance of muscle protein metabolism. Diabetologia 52 1889-1898. (doi:10.1007/s00125-009-1430-8)

Fukagawa NK, Minaker KL, Rowe JW, Goodman MN, Matthews DE, Bier DM \& Young VR 1985 Insulin-mediated reduction of whole body protein breakdown. Dose-response effects on leucine metabolism in postabsorptive men. Journal of Clinical Investigation 76 2306-2311. (doi:10.1172/JCI112240)

Gao W, Reiser PJ, Coss CC, Phelps MA, Kearbey JD, Miller DD \& Dalton JT 2005 Selective androgen receptor modulator treatment improves muscle strength and body composition and prevents bone loss in orchidectomized rats. Endocrinology 146 4887-4897. (doi:10.1210/en.2005-0572)

Gardiner PF, Hibl B, Simpson DR, Roy R \& Edgerton VR 1980 Effects of a mild weight-lifting program on the progress of glucocorticoidinduced atrophy in rat hindlimb muscles. Pflugers Archiv $\mathbf{3 8 5}$ 147-153. (doi:10.1007/BF00588695)

Gelfand RA \& Barrett EJ 1987 Effect of physiologic hyperinsulinemia on skeletal muscle protein synthesis and breakdown in man. Journal of Clinical Investigation 80 1-6. (doi:10.1172/JCI113033)

Genton L, Karsegard VL, Chevalley T, Kossovsky MP, Darmon P \& Pichard C 2011 Body composition changes over 9 years in healthy elderly subjects and impact of physical activity. Clinical Nutrition $\mathbf{3 0}$ 436-442. (doi:10.1016/j.clnu.2011.01.009)

Giannoulis MG, Martin FC, Nair KS, Umpleby AM \& Sonksen P 2012 Hormone replacement therapy and physical function in healthy older men. Time to talk hormones? Endocrine Reviews 33 314-377. (doi:10.1210/er.2012-1002)

Giordano M, Castellino P \& DeFronzo RA 1996 Differential responsiveness of protein synthesis and degradation to amino acid availability in humans. Diabetes 45 393-399. (doi:10.2337/ diab.45.4.393)

Goodpaster BH, Park SW, Harris TB, Kritchevsky SB, Nevitt M, Schwartz AV, Simonsick EM, Tylavsky FA, Visser M \& Newman AB 2006 The loss of skeletal muscle strength, mass, and quality in older adults: the health, aging and body composition study. Journals of Gerontology. Series A, Biological Sciences and Medical Sciences 61 1059-1064. (doi:10.1093/gerona/61.10.1059)

Groen BB, Hamer HM, Snijders T, van Kranenburg J, Frijns D, Vink H \& van Loon LJ 2014 Skeletal muscle capillary density and microvascular function are compromised with aging and type 2 diabetes. Journal of Applied Physiology 116 998-1005.

Guillet C, Prod'homme M, Balage M, Gachon P, Giraudet C, Morin L, Grizard J \& Boirie Y 2004a Impaired anabolic response of muscle protein synthesis is associated with S6K1 dysregulation in elderly humans. FASEB Journal 18 1586-1587.

Guillet C, Zangarelli A, Gachon P, Morio B, Giraudet C, Rousset P \& Boirie Y $2004 b$ Whole body protein breakdown is less inhibited by insulin, but still responsive to amino acid, in nondiabetic elderly subjects. Journal of Clinical Endocrinology and Metabolism 89 6017-6024.

Guillet C, Delcourt I, Rance M, Giraudet C, Walrand S, Bedu M, Duche P \& Boirie Y 2009 Changes in basal and insulin and amino acid response of whole body and skeletal muscle proteins in obese men. Journal of Clinical Endocrinology and Metabolism 94 3044-3050. (doi:10.1210/jc.2008-2216)

Gumbiner B, Thorburn AW, Ditzler TM, Bulacan F \& Henry RR 1992 Role of impaired intracellular glucose metabolism in the insulin resistance of aging. Metabolism 41 1115-1121. (doi:10.1016/00260495(92)90296-M)

Guo T, Jou W, Chanturiya T, Portas J, Gavrilova O \& McPherron AC 2009 Myostatin inhibition in muscle, but not adipose tissue, decreases fat mass and improves insulin sensitivity. PLoS One 4 e4937.
Hevener AL, Olefsky JM, Reichart D, Nguyen MT, Bandyopadyhay G, Leung HY, Watt MJ, Benner C, Febbraio MA, Nguyen AK, et al. 2007 Macrophage PPAR gamma is required for normal skeletal muscle and hepatic insulin sensitivity and full antidiabetic effects of thiazolidinediones. Journal of Clinical Investigation 117 1658-1669. (doi:10.1172/JCI31561)

Hill EW, Gu J, Eivers SS, Fonseca RG, McGivney BA, Govindarajan P, Orr N, Katz LM \& MacHugh DE 2010 A sequence polymorphism in MSTN predicts sprinting ability and racing stamina in thoroughbred horses. PLoS One 5 e8645. (doi:10.1371/journal.pone.0008645)

IDF 2013 IDF Diabetes Atlas. 6th edn. Brussles, Belgium: International Diabetes Federation. (available at: http://www.idf.org/sites/default/ files/EN_6E_Atlas_Full_0.pdf).

Jamieson PM, Cleasby ME, Kuperman Y, Morton NM, Kelly PA, Brownstein DG, Mustard KJ, Vaughan JM, Carter RN, Hahn CN, et al. 2011 Urocortin 3 transgenic mice exhibit a metabolically favourable phenotype resisting obesity and hyperglycaemia on a high-fat diet. Diabetologia 54 2392-2403. (doi:10.1007/s00125-0112205-6)

Janssen I, Heymsfield SB \& Ross R 2002 Low relative skeletal muscle mass (sarcopenia) in older persons is associated with functional impairment and physical disability. Journal of the American Geriatrics Society 50 889-896. (doi:10.1046/j.1532-5415.2002.50216.x)

Johannsen DL, Conley KE, Bajpeyi S, Punyanitya M, Gallagher D, Zhang Z, Covington J, Smith SR \& Ravussin E 2012 Ectopic lipid accumulation and reduced glucose tolerance in elderly adults are accompanied by altered skeletal muscle mitochondrial activity. Journal of Clinical Endocrinology and Metabolism 97 242-250. (doi:10.1210/jc.2011-1798)

Katta A, Kundla S, Kakarla SK, Wu M, Fannin J, Paturi S, Liu H, Addagarla HS \& Blough ER 2010 Impaired overload-induced hypertrophy is associated with diminished mTOR signaling in insulin-resistant skeletal muscle of the obese Zucker rat. American Journal of Physiology: Regulatory, Integrative and Comparative Physiology 299 R1666-R1675.

Kim TN, Park MS, Yang SJ, Yoo HJ, Kang HJ, Song W, Seo JA, Kim SG, Kim NH, Baik SH, et al. 2010 Prevalence and determinant factors of sarcopenia in patients with type 2 diabetes: the Korean Sarcopenic Obesity Study (KSOS). Diabetes Care 33 1497-1499. (doi:10.2337/ dc09-2310)

Kim TN, Park MS, Ryu JY, Choi HY, Hong HC, Yoo HJ, Kang HJ, Song W, Park SW, Baik SH, et al. 2014 Impact of visceral fat on skeletal muscle mass and vice versa in a prospective cohort study: the Korean Sarcopenic Obesity Study (KSOS). PLoS One 9 e115407.

Kimball SR, Horetsky RL \& Jefferson LS 1998 Signal transduction pathways involved in the regulation of protein synthesis by insulin in L6 myoblasts. American Journal of Physiology 274 C221-C228.

Klein CS, Allman BL, Marsh GD \& Rice CL 2002 Muscle size, strength, and bone geometry in the upper limbs of young and old men. Journals of Gerontology. Series A, Biological Sciences and Medical Sciences 57 M455-M459.

Koh HJ, Brandauer J \& Goodyear LJ 2008 LKB1 and AMPK and the regulation of skeletal muscle metabolism. Current Opinion in Clinical Nutrition and Metabolic Care 11 227-232. (doi:10.1097/ MCO.0b013e3282fb7b76)

Landi F, Cruz-Jentoft AJ, Liperoti R, Russo A, Giovannini S, Tosato M, Capoluongo E, Bernabei R \& Onder G 2013 Sarcopenia and mortality risk in frail older persons aged 80 years and older: results from ilSIRENTE study. Age and Ageing 42 203-209. (doi:10.1093/ageing/ afs194)

Laurens C, Louche K, Sengenes C, Coue M, Langin D, Moro C \& Bourlier V 2016 Adipogenic progenitors from obese human skeletal muscle give rise to functional white adipocytes that contribute to insulin resistance. International Journal of Obesity 31 585-595. (doi:10.1002/jbmr.2729) http://joe.endocrinology-journals.org

DOI: 10.1530/JOE-15-0533
C 2016 Society for Endocrinology Printed in Great Britain 
Lee JS, Auyeung TW, Kwok T, Lau EM, Leung PC \& Woo J 2007 Associated factors and health impact of sarcopenia in older chinese men and women: a cross-sectional study. Gerontology 53 404-410. (doi:10.1159/000107355)

Leger B, Derave W, De Bock K, Hespel P \& Russell AP 2008 Human sarcopenia reveals an increase in SOCS-3 and myostatin and a reduced efficiency of Akt phosphorylation. Rejuvenation Research 11 163-175B.

Lexell J 1995 Human aging, muscle mass, and fiber type composition. Journals of Gerontology. Series A, Biological Sciences and Medical Sciences 50 11-16.

Lillioja S, Young AA, Culter CL, Ivy JL, Abbott WG, Zawadzki JK, Yki-Jarvinen H, Christin L, Secomb TW \& Bogardus C 1987 Skeletal muscle capillary density and fiber type are possible determinants of in vivo insulin resistance in man. Journal of Clinical Investigation $\mathbf{8 0}$ 415-424. (doi:10.1172/JCI113088)

Liu Y, Palanivel R, Rai E, Park M, Gabor TV, Scheid MP, Xu A \& Sweeney G 2015 Adiponectin stimulates autophagy and reduces oxidative stress to enhance insulin sensitivity during high-fat diet feeding in mice. Diabetes 64 36-48. (doi:10.2337/db14-0267)

Lumeng CN, Bodzin JL \& Saltiel AR 2007 Obesity induces a phenotypic switch in adipose tissue macrophage polarization. Journal of Clinical Investigation 117 175-184. (doi:10.1172/JCI29881)

Lu-Nguyen NB, Jarmin SA, Saleh AF, Popplewell L, Gait MJ \& Dickson G 2015 Combination Antisense Treatment for Destructive Exon Skipping of Myostatin and Open Reading Frame Rescue of Dystrophin in Neonatal mdx Mice. Molecular Therapy 23 1341-1348. (doi:10.1038/mt.2015.88)

Manini TM \& Clark BC 2012 Dynapenia and aging: an update. Journals of Gerontology. Series A, Biological Sciences and Medical Sciences 67 28-40. (doi:10.1093/gerona/glr010)

Masgrau A, Mishellany-Dutour A, Murakami H, Beaufrere AM, Walrand S, Giraudet C, Migne C, Gerbaix M, Metz L, Courteix D, et al. 2012 Time-course changes of muscle protein synthesis associated with obesity-induced lipotoxicity. Journal of Physiology 590 5199-5210. (doi:10.1113/jphysiol.2012.238576)

McPherron AC, Lawler AM \& Lee SJ 1997 Regulation of skeletal muscle mass in mice by a new TGF-beta superfamily member. Nature $\mathbf{3 8 7}$ 83-90. (doi:10.1038/387083a0)

Min L, Yanase T, Tanaka T, Fan W, Nomura M, Kawate H, Okabe T, Takayanagi R \& Nawata H 2009 A novel synthetic androgen receptor ligand, S42, works as a selective androgen receptor modulator and possesses metabolic effects with little impact on the prostate. Endocrinology 150 5606-5616.

Morley JE, Abbatecola AM, Argiles JM, Baracos V, Bauer J, Bhasin S, Cederholm T, Coats AJ, Cummings SR, Evans WJ, et al. 2011 Sarcopenia with limited mobility: an international consensus. Journal of the American Medical Directors Association 12 403-409. (doi:10.1016/j.jamda.2011.04.014)

Mounier R, Theret M, Lantier L, Foretz M \& Viollet B 2015 Expanding roles for AMPK in skeletal muscle plasticity. Trends in Endocrinology and Metabolism 26 275-286. (doi:10.1016/j.tem.2015.02.009)

Mourkioti F, Kratsios P, Luedde T, Song YH, Delafontaine P, Adami R, Parente V, Bottinelli R, Pasparakis M \& Rosenthal N 2006 Targeted ablation of IKK2 improves skeletal muscle strength, maintains mass, and promotes regeneration. Journal of Clinical Investigation $\mathbf{1 1 6}$ 2945-2954. (doi:10.1172/JCI28721)

Muller FL, Song W, Jang YC, Liu Y, Sabia M, Richardson A \& Van Remmen H 2007 Denervation-induced skeletal muscle atrophy is associated with increased mitochondrial ROS production. American Journal of Physiology: Regulatory, Integrative and Comparative Physiology 293 R1159-R1168.

Muller MJ, Lagerpusch M, Enderle J, Schautz B, Heller M \& BosyWestphal A 2012 Beyond the body mass index: tracking body composition in the pathogenesis of obesity and the metabolic syndrome. Obesity Reviews 13 (Supplement 2) 6-13.
Murton AJ, Marimuthu K, Mallinson JE, Selby AL, Smith K, Rennie MJ \& Greenhaff PL 2015 Obesity appears to be associated with altered muscle protein synthetic and breakdown responses to increased nutrient delivery in older men, but not reduced muscle mass or contractile function. Diabetes 64 3160-3171. (doi:10.2337/db15-0021)

Nakashima K \& Yakabe Y 2007 AMPK activation stimulates myofibrillar protein degradation and expression of atrophy-related ubiquitin ligases by increasing FOXO transcription factors in $\mathrm{C} 2 \mathrm{C} 12$ myotubes. Bioscience, Biotechnology, and Biochemistry 71 1650-1656. (doi:10.1271/bbb.70057)

Narvaez CJ, Matthews D, Broun E, Chan M \& Welsh J 2009 Lean phenotype and resistance to diet-induced obesity in vitamin D receptor knockout mice correlates with induction of uncoupling protein-1 in white adipose tissue. Endocrinology 150 651-661. (doi:10.1210/en.2008-1118)

Newman AB, Kupelian V, Visser M, Simonsick E, Goodpaster B, Nevitt M, Kritchevsky SB, Tylavsky FA, Rubin SM \& Harris TB 2003 Sarcopenia: alternative definitions and associations with lower extremity function. Journal of the American Geriatrics Society 51 1602-1609. (doi:10.1046/j.1532-5415.2003.51534.x)

Nilsson MI, Dobson JP, Greene NP, Wiggs MP, Shimkus KL, Wudeck EV, Davis AR, Laureano ML \& Fluckey JD 2013 Abnormal protein turnover and anabolic resistance to exercise in sarcopenic obesity. FASEB Journal 27 3905-3916. (doi:10.1096/fj.12-224006)

Oberbach A, Bossenz Y, Lehmann S, Niebauer J, Adams V, Paschke R, Schon MR, Bluher M \& Punkt K 2006 Altered fiber distribution and fiber-specific glycolytic and oxidative enzyme activity in skeletal muscle of patients with type 2 diabetes. Diabetes Care 29 895-900. (doi:10.2337/diacare.29.04.06.dc05-1854)

Park SW, Goodpaster BH, Lee JS, Kuller LH, Boudreau R, de Rekeneire N, Harris TB, Kritchevsky S, Tylavsky FA, Nevitt M, et al. 2009 Excessive loss of skeletal muscle mass in older adults with type 2 diabetes. Diabetes Care 32 1993-1997. (doi:10.2337/dc09-0264)

Park H, Park S, Shephard RJ \& Aoyagi Y 2010 Yearlong physical activity and sarcopenia in older adults: the Nakanojo Study. European Journal of Applied Physiology 109 953-961. (doi:10.1007/s00421-010-1424-8)

Patel SA, Hoehn KL, Lawrence RT, Sawbridge L, Talbot NA, Tomsig JL, Turner N, Cooney GJ, Whitehead JP, Kraegen EW, et al. 2012 Overexpression of the adiponectin receptor AdipoR1 in rat skeletal muscle amplifies local insulin sensitivity. Endocrinology 153 5231-5246. (doi:10.1210/en.2012-1368)

Pellegrinelli V, Rouault C, Rodriguez-Cuenca S, Albert V, Edom-Vovard F, Vidal-Puig A, Clement K, Butler-Browne GS \& Lacasa D 2015 Human adipocytes induce inflammation and atrophy in muscle cells during obesity. Diabetes 64 3121-3134. (doi:10.2337/db14-0796)

Polkinghorne E, Lau Q, Cooney GJ, Kraegen EW \& Cleasby ME 2008 Local activation of the I\{kappa\}K-NF\{kappa\}B pathway in muscle does not cause insulin resistance. American Journal of Physiology. Endocrinology and Metabolism 294 E316-E325.

Raguso CA, Kyle U, Kossovsky MP, Roynette C, Paoloni-Giacobino A, Hans D, Genton L \& Pichard C 2006 A 3-year longitudinal study on body composition changes in the elderly: role of physical exercise. Clinical Nutrition 25 573-580. (doi:10.1016/j.clnu.2005.10.013)

Raschke S, Elsen M, Gassenhuber H, Sommerfeld M, Schwahn U, Brockmann B, Jung R, Wisloff U, Tjonna AE, Raastad T, et al. 2013 Evidence against a beneficial effect of irisin in humans. PLoS One $\mathbf{8}$ e73680.

Rasmussen BB, Fujita S, Wolfe RR, Mittendorfer B, Roy M, Rowe VL \& Volpi E 2006 Insulin resistance of muscle protein metabolism in aging. FASEB Journal 20 768-769.

Ratkevicius A, Joyson A, Selmer I, Dhanani T, Grierson C, Tommasi AM, DeVries A, Rauchhaus P, Crowther D, Alesci S, et al. 2011 Serum concentrations of myostatin and myostatin-interacting proteins do not differ between young and sarcopenic elderly men. Journals of Gerontology. Series A, Biological Sciences and Medical Sciences 66 620-626.

Published by Bioscientifica Ltd. 
Roustit MM, Vaughan JM, Jamieson PM \& Cleasby ME 2014 Urocortin 3 activates AMPK and AKT pathways and enhances glucose disposal in rat skeletal muscle. Journal of Endocrinology 223 143-154. (doi:10.1530/JOE-14-0181)

Ryu M, Jo J, Lee Y, Chung YS, Kim KM \& Baek WC 2013 Association of physical activity with sarcopenia and sarcopenic obesity in community-dwelling older adults: the Fourth Korea National Health and Nutrition Examination Survey. Age and Ageing 42 734-740. (doi:10.1093/ageing/aft063)

Sandri M, Barberi L, Bijlsma AY, Blaauw B, Dyar KA, Milan G, Mammucari C, Meskers CG, Pallafacchina G, Paoli A, et al. 2013 Signalling pathways regulating muscle mass in ageing skeletal muscle: the role of the IGF1-Akt-mTOR-FoxO pathway. Biogerontology 14 303-323. (doi:10.1007/s10522-013-9432-9)

Sayer AA, Syddall H, Martin H, Patel H, Baylis D \& Cooper C 2008 The developmental origins of sarcopenia. Journal of Nutrition, Health \& Aging 12 427-432.

Schiaffino S, Dyar KA, Ciciliot S, Blaauw B \& Sandri M 2013 Mechanisms regulating skeletal muscle growth and atrophy. FEBS Journal 280 4294-4314. (doi:10.1111/febs.2013.280.issue-17)

Schubert L \& DeLuca HF 2010 Hypophosphatemia is responsible for skeletal muscle weakness of vitamin D deficiency. Archives of Biochemistry and Biophysics 500 157-161. (doi:10.1016/j. abb.2010.05.029)

Scott D, Blizzard L, Fell J \& Jones G 2011 Prospective associations between ambulatory activity, body composition and muscle function in older adults. Scandinavian Journal of Medicine \& Science in Sports 21 e168-e175.

Scott D, Sanders KM, Aitken D, Hayes A, Ebeling PR \& Jones G 2014 Sarcopenic obesity and dynapenic obesity: 5-year associations with falls risk in middle-aged and older adults. Obesity 22 1568-1574. (doi:10.1002/oby.20734)

Scott D, Trbojevic T, Skinner E, Clark RA, Levinger P, Haines TP, Sanders KM \& Ebeling PR 2015 Associations of calf inter- and intra-muscular adipose tissue with cardiometabolic health and physical function in community-dwelling older adults. Journal of Musculoskeletal \& Neuronal Interactions 15 350-357.

Shan T, Zhang P, Liang X, Bi P, Yue F \& Kuang S 2014 Lkb1 is indispensable for skeletal muscle development, regeneration, and satellite cell homeostasis. Stem Cells 32 2893-2907. (doi:10.1002/ stem.1788)

Sishi B, Loos B, Ellis B, Smith W, du Toit EF \& Engelbrecht AM 2011 Dietinduced obesity alters signalling pathways and induces atrophy and apoptosis in skeletal muscle in a prediabetic rat model. Experimental Physiology 96 179-193. (doi:10.1113/expphysiol.2010.054189)

Skelton DA, Young A, Greig CA \& Malbut KE 1995 Effects of resistance training on strength, power, and selected functional abilities of women aged 75 and older. Journal of the American Geriatrics Society $\mathbf{4 3}$ 1081-1087.

Stephens FB, Chee C, Wall BT, Murton AJ, Shannon CE, van Loon LJ \& Tsintzas K 2015 Lipid-induced insulin resistance is associated with an impaired skeletal muscle protein synthetic response to amino acid ingestion in healthy young men. Diabetes 64 1615-1620. (doi:10.2337/db14-0961)

Steven S \& Taylor R 2015 Restoring normoglycaemia by use of a very low calorie diet in long- and short-duration Type 2 diabetes. Diabetic Medicine 32 1149-1155. (doi:10.1111/dme.12722)

Stuart CA, McCurry MP, Marino A, South MA, Howell ME, Layne AS, Ramsey MW \& Stone MH 2013 Slow-twitch fiber proportion in skeletal muscle correlates with insulin responsiveness. Journal of Clinical Endocrinology and Metabolism 98 2027-2036. (doi:10.1210/ jc.2012-3876)

Szulc P, Duboeuf F, Marchand F \& Delmas PD 2004 Hormonal and lifestyle determinants of appendicular skeletal muscle mass in men: the MINOS study. American Journal of Clinical Nutrition 80 496-503.
Talaei A, Mohamadi M \& Adgi Z 2013 The effect of vitamin D on insulin resistance in patients with type 2 diabetes. Diabetology \& Metabolic Syndrome 58.

Talbot NA, Wheeler-Jones CP \& Cleasby ME 2014 Palmitoleic acid prevents palmitic acid-induced macrophage activation and consequent p38 MAPK-mediated skeletal muscle insulin resistance. Molecular and Cellular Endocrinology 393 129-142. (doi:10.1016/j. mce.2014.06.010)

Tam CS, Sparks LM, Johannsen DL, Covington JD, Church TS \& Ravussin E 2012 Low macrophage accumulation in skeletal muscle of obese type 2 diabetics and elderly subjects. Obesity 20 1530-1533. (doi:10.1038/oby.2012.24)

Tardif N, Salles J, Landrier JF, Mothe-Satney I, Guillet C, Boue-Vaysse C, Combaret L, Giraudet C, Patrac V, Bertrand-Michel J, et al. 2011 Oleate-enriched diet improves insulin sensitivity and restores muscle protein synthesis in old rats. Clinical Nutrition 30 799-806. (doi:10.1016/j.clnu.2011.05.009)

Tardif N, Salles J, Guillet C, Tordjman J, Reggio S, Landrier JF, Giraudet C, Patrac V, Bertrand-Michel J, Migne C, et al. 2014 Muscle ectopic fat deposition contributes to anabolic resistance in obese sarcopenic old rats through eIF2alpha activation. Aging Cell 13 1001-1011. (doi:10.1111/acel.12263)

Temparis S, Asensi M, Taillandier D, Aurousseau E, Larbaud D, Obled A, Bechet D, Ferrara M, Estrela JM \& Attaix D 1994 Increased ATPubiquitin-dependent proteolysis in skeletal muscles of tumor-bearing rats. Cancer Research $\mathbf{5 4} 5568-5573$.

Thomson DM \& Gordon SE 2005 Diminished overload-induced hypertrophy in aged fast-twitch skeletal muscle is associated with AMPK hyperphosphorylation. Journal of Applied Physiology 98 557-564. (doi:10.1152/japplphysiol.00811.2004)

Timmerman KL, Lee JL, Fujita S, Dhanani S, Dreyer HC, Fry CS, Drummond MJ, Sheffield-Moore M, Rasmussen BB \& Volpi E 2010 Pharmacological vasodilation improves insulin-stimulated muscle protein anabolism but not glucose utilization in older adults. Diabetes 59 2764-2771. (doi:10.2337/db10-0415)

Timmons JA, Baar K, Davidsen PK \& Atherton PJ 2012 Is irisin a human exercise gene? Nature 488 E9-E10; discussion E10-E11.

Traish AM, Saad F \& Guay A 2009 The dark side of testosterone deficiency: II. Type 2 diabetes and insulin resistance. Journal of Andrology 30 23-32. (doi:10.2164/jandrol.108.005751)

Turner N, Cooney GJ, Kraegen EW \& Bruce CR 2014 Fatty acid metabolism, energy expenditure and insulin resistance in muscle. Journal of Endocrinology 220 T61-T79. (doi:10.1530/JOE-13-0397)

Ussher JR, Koves TR, Cadete VJ, Zhang L, Jaswal JS, Swyrd SJ, Lopaschuk DG, Proctor SD, Keung W, Muoio DM, et al. 2010 Inhibition of de novo ceramide synthesis reverses diet-induced insulin resistance and enhances whole-body oxygen consumption. Diabetes 59 2453-2464. (doi:10.2337/db09-1293)

Varma V, Yao-Borengasser A, Rasouli N, Nolen GT, Phanavanh B, Starks T, Gurley C, Simpson P, McGehee RE Jr, Kern PA, et al. 2009 Muscle inflammatory response and insulin resistance: synergistic interaction between macrophages and fatty acids leads to impaired insulin action. American Journal of Physiology: Endocrinology and Metabolism 296 E1300-E1310.

Verreijen AM, Verlaan S, Engberink MF, Swinkels S, de Vogel-van den Bosch J \& Weijs PJ 2015 A high whey protein-, leucine-, and vitamin D-enriched supplement preserves muscle mass during intentional weight loss in obese older adults: a double-blind randomized controlled trial. American Journal of Clinical Nutrition 101 279-286. (doi:10.3945/ajcn.114.090290)

Vincent KR, Braith RW, Feldman RA, Magyari PM, Cutler RB, Persin SA, Lennon SL, Gabr AH \& Lowenthal DT 2002 Resistance exercise and physical performance in adults aged 60 to 83. Journal of the American Geriatrics Society 50 1100-1107. (doi:10.1046/j.15325415.2002.50267.x) http://joe.endocrinology-journals.org

DOI: 10.1530/JOE-15-0533
C 2016 Society for Endocrinology Printed in Great Britain 
Wang X, Hu Z, Hu J, Du J \& Mitch WE 2006 Insulin resistance accelerates muscle protein degradation: Activation of the ubiquitin-proteasome pathway by defects in muscle cell signaling. Endocrinology 147 4160-4168. (doi:10.1210/en.2006-0251)

Wang Y, Wehling-Henricks M, Samengo G \& Tidball JG 2015 Increases of M2a macrophages and fibrosis in aging muscle are influenced by bone marrow aging and negatively regulated by muscle-derived nitric oxide. Aging Cell 14 678-688. (doi:10.1111/acel.2015.14. issue-4)

Wenz T, Rossi SG, Rotundo RL, Spiegelman BM \& Moraes CT 2009 Increased muscle PGC-1alpha expression protects from sarcopenia and metabolic disease during aging. PNAS 106 20405-20410. (doi:10.1073/pnas.0911570106)

Wilkes EA, Selby AL, Atherton PJ, Patel R, Rankin D, Smith K \& Rennie MJ 2009 Blunting of insulin inhibition of proteolysis in legs of older subjects may contribute to age-related sarcopenia. American Journal of Clinical Nutrition 90 1343-1350. (doi:10.3945/ajcn.2009.27543)

Wolfe RR 2006 The underappreciated role of muscle in health and disease. American Journal of Clinical Nutrition 84 475-482.

Wong KE, Szeto FL, Zhang W, Ye H, Kong J, Zhang Z, Sun XJ \& Li YC 2009 Involvement of the vitamin D receptor in energy metabolism: regulation of uncoupling proteins. American Journal of Physiology. Endocrinology and Metabolism 296 E820-E828.

Wongwiwatthananukit S, Sansanayudh N, Phetkrajaysang N \& Krittiyanunt S 2013 Effects of vitamin D(2) supplementation on insulin sensitivity and metabolic parameters in metabolic syndrome patients. Journal of Endocrinological Investigation 36 558-563.

Yoshimura E, Kumahara H, Tobina T, Matsuda T, Watabe K, Matono S, Ayabe M, Kiyonaga A, Anzai K, Higaki Y, et al. 2014 Aerobic exercise attenuates the loss of skeletal muscle during energy restriction in adults with visceral adiposity. Obesity Facts 7 26-35. (doi:10.1159/000358576)

Zhang C, McFarlane C, Lokireddy S, Bonala S, Ge X, Masuda S, Gluckman PD, Sharma M \& Kambadur R 2011 Myostatin-deficient mice exhibit reduced insulin resistance through activating the AMP-activated protein kinase signalling pathway. Diabetologia 54 1491-1501. (doi:10.1007/s00125-011-2079-7)

Zhang C, McFarlane C, Lokireddy S, Masuda S, Ge X, Gluckman PD, Sharma M \& Kambadur R 2012 Inhibition of myostatin protects against diet-induced obesity by enhancing fatty acid oxidation and promoting a brown adipose phenotype in mice. Diabetologia 55 183-193. (doi:10.1007/s00125-011-2304-4)

Received in final form 10 February 2016

Accepted 1 March 2016

Accepted Preprint published online 1 March 2016
(C) 2016 Society for Endocrinology Printed in Great Britain
Published by Bioscientifica Ltd. 